Long Wharf "was the landing place for old Commodore Sturgis, of revenue cutter fame, and point of arrival and departure of the Custom House boarding officers, and the news boat in command of Clive." For a period prior to 1845 , the Wharf was in the doldrums, but in that year John $\mathbf{H}$. Pearson leased the property, and for fifteen years it was probably Boston's best paying wharf property.

After the middle of the I 800's, Long Wharf began to lose ground to newer and more advantageously placed wharves. Probably a major factor in its decline were the reclamation projects which were increasing the land area of Boston. By 1874 a large portion of Great or Town Cove, on which the pier is located, had been reclaimed, and as a result Long Wharf lost most of its length to State (King) Street.

\title{
Government Archives Building
}

Sometime within the next six months it is believed that the new Government Archives Building at Washington, D. C., will be completed; and at this time the Federal Government will finally have a central depository for all of its old and valuable documents. Work began on the massive vault building, located halfway between the White House and the Capitol Building, about a year and a half ago, and the earliest possible completion date is now set for July I.

Completion of the Archives Building will mean that the thousands of letters, documents, and records heretofore scattered in outof-the-way storage spaces throughout the many Government buildings will now be brought together in one convenient and easily accessible home. What is more this building is being constructed with the intention of minimizing the forces that lead to deterioration and destruction of valued papers. Every conceivable device is being employed to combat the bad effects of sunshine, inadequate ventilation, and improper humidity.

For years historians and others desirous of preserving important governmental records have worked for the erection of such a building. Among these public-spirited individuals have been a number of Business Historical Society members. A few years ago when tons of United States Internal Revenue manuscripts were ordered burned these persons interceded, and as a result Washington officials decided that the papers should be preserved. 
Because of the inadequate facilities previously provided there have been repeated losses caused by fires, carelessness of research workers, the maraudings of souvenir hunters, and the general deterioration that comes from too much light and ventilation. Twice in the early part of the nineteenth century the War Department files were mutilated by conflagrations, and in 1836 a fire wiped out the Post Office records. Then a few years ago a fire in the Executive Office of the White House damaged certain letter files, and quite recently a blaze in the attic of the House of Representatives Building took a heavy toll.

In order to provide for the administration of the Archives Building when it is completed, the Federal Congress passed an Act last June which sets up the administrative organization. The Office of Archivist of the United States was created, and since that time President Roosevelt has appointed Robert D. W. Connor, Professor of American History at the University of North Carolina and Archivist of the University of North Carolina from I9I3 to I921, to the Office. The Congressional Act also provided for the establishment of the National Historical Publications Commission which will make plans for the publication of appropriate historical works and collections of sources. In addition there was created the National Archives Council, composed of the Secretaries of the executive departments of the Government. "The Council shall define the classes of material which shall be transferred to the National Archives Building and establish regulations governing such transfer."

Before construction started on the Archives Building, a great deal of preliminary work had been done. Several persons from the staff of the Bureau of Standards conducted intensive research into the best methods of guarding against the deteriorating effects of sunlight and improper moisture and ventilation. European depositories for governmental records were studied by a representative of the supervising architect's office sent over by the Treasury Department. The findings of these investigations have resulted in the designing of the building in such a way that daylight will be excluded from the storage spaces. There will be few doors and windows in this area of the structure, and lighting will be entirely artificial. An air conditioning system capable of treating 330,000 cubic feet of air a minute will be installed which will make it possible to maintain a fifty-five per cent relative humidity in the storerooms and a forty-five per cent relative humidity in the work- 
rooms. During the winter the temperature will be held at seventy degrees, while in the summer there will be a constant temperature of eighty degrees.

On the main floor of the Archives Building in addition to the entrances, waiting room, lobbies, and administrative offices there will be a semicircular exhibition hall containing special cases for the display of historical documents. There will be two research rooms on the second floor, one a public room and the other an official research room. The main entrance will be guarded by the two largest portals in the world. These doors are each thirty-five feet high, nine feet wide, and a foot thick.

The Government Archives Building will be equipped with highly specialized devices for mounting, repairing, cleaning, and arranging papers. There will be elaborate equipment for copying, duplicating, cataloguing, indexing, and photographing.

\section{The Persistent Fringe of House to House Selling in American History}

"Goon morning, Madame! I am working my way through college and have called on you today in order to obtain your help. For the paltry sum of seven cents a week you can assist me in my project, and what is more you can provide yourself with the world's best magazine." What modern woman has not on a hundred occasions heard these or similar words poured from the mouth of an effervescent young man confidently poised on the front door step. Turn back time one hundred years and we find another American housewife, living in an unfrequented hamlet, who has been greeted by an assuming young fellow with words to this effect, "Madame, are you in need of any pocket sawmills? Horn gunflints? Wooden nutmegs? White oak cheeses? Tin bungholes? Or calico hogtroughs?" I Having gained the attention and smile of this housewife, the peddler would then have launched into a laudation of his wares.

Apparently peddling or house-to-house selling has always been a recognized part of the American marketing system, and evidences of the persistent fringe of this distribution device may be found in the manuscript collection of the Baker Library. Certain market-

1 "Hawkers and Walkers in Early America," by Richardson Wright. 